\title{
Message from the President / Message du président
}

Dear CAML Members,

With my term as CAML President drawing to its end, I am reminded of the unique difficulties of the last two years. CAML members have experienced loss, illness, financial hardship, cancelled travel plans, and isolation. But this period was also marked by birth, healing, renewal of purpose, interdependence, and exceptional outreach. Our computer screens are not making up for the lost in-person contact, but have allowed us to connect more often, and to interact with colleagues we would not have seen or heard from otherwise. In hindsight, I am most grateful to have served you during this period, which highlighted your resilience and reiterated your commitment to our community of practice. Thank you for the privilege and the support that you accorded me along the way! I am confident that CAML is poised to begin an exciting journey into its next 50 years.

Our upcoming conference, CAML at 50: Reflections and Renewal, will offer a full program over three abridged days, with breaks and social moments. We will begin on Monday, June 7 with an opening celebration, and the anniversary theme will continue throughout the conference. This year's presentations will cover a variety of topics, from equity, diversity, and inclusion issues in libraries, to the history of music librarianship in Canada, towards archival
Chers membres de l'ACBM,

Mon mandat de président tire à sa fin, et je me rappelle les difficultés particulières aux deux dernières années. Les membres de l'ACBM ont connu pertes, maladie, difficultés financières et isolement, et ont dû annuler des voyages. Toutefois, cette période a aussi été caractérisée par le renouveau, la guérison, un engagement renouvelé, l'interdépendance et une entraide exceptionnelle. Nos écrans ne compensent pas le manque de contact personnel, mais ils nous permettent d'être en communication plus souvent et $d$ 'interagir avec des collègues avec qui nous n'aurions pas communiqué autrement. En prenant un recul, je suis très reconnaissant d'avoir pu vous servir durant cette période qui a fait ressortir votre résilience et votre engagement à l'égard de notre communauté de pratique. Je vous remercie du privilège que vous $m^{\prime}$ avez accordé de vous servir, ainsi que du soutien que vous m'avez apporté durant mon mandat. Je suis persuadé que l'ACBM est bien positionnée pour entamer avec enthousiasme les 50 prochaines années.

Le programme du congrès à venir sera chargé. Intitulé « L'ACBM a 50 ans : Réflexions et renouveau ", cet événement se tiendra sur trois journées écourtées qui incluront des moments de pause et de socialisation. Une cérémonie d'ouverture aura lieu le lundi 7 juin. Tout en soutenant le thème, les présentations de cette année porteront sur une variété de sujets allant de l'équité, de la diversité et de l'inclusion dans les bibliothèques à l'histoire des bibliothèques de musique au Canada et aux initiatives d'archivage 
initiatives to secure our musical record for future generations.

Organizing CAML's first virtual conference was novel to all of us and took a substantial amount of planning, attention to detail, and diligence from the Board members, as well as our 2021 Program Chair Alastair Boyd. The Conference Planning Committee met on a bi-weekly basis from September 2020, overseeing all aspects of the program and its technological requirements. We remained committed to the documentation of our work processes, something we hope would be beneficial to future conference organizers. I would like to express my gratitude to Alastair Boyd, Lucinda Johnston, and Trevor Deck who joined me in the planning exercise, and to Marc Stoeckle (web management), Rebecca Smith and Timothy Neufeldt (registration and financial aspects), and Maureen Nevins for her guidance and commitment to inclusivity throughout the process. It took a village!

The CAML Renewal Task Force continued its monthly meetings and organized two Town Halls in March 2021 to solicit additional feedback on the final draft of the CAML Strategic Directions (SD) document. We benefited greatly from your lively participation and valuable feedback at both Town Halls. Consequently, the SD document incorporated the recommendations put forward by the Town Hall participants. The final SD document is included in this issue of CAML Review and will be launched on June 7 as part of the conference program. On June 8 , we will have an open discussion veillant à préserver une documentation musicale pour les générations à venir.

L'organisation d'un congrès virtuel était tout nouveau pour chacun de nous et a exigé beaucoup de planification et de diligence, ainsi qu'une grande attention aux détails de la part des membres du CA, de même que du président du comité du programme cette année, Alastair Boyd. Les membres du comité organisateur se sont rencontrés toutes les deux semaines à compter de septembre 2020 pour coordonner tous les aspects du programme et ses exigences technologiques. Nous avons pris soin de documenter chaque étape, et nous espérons que ces renseignements serviront aux prochains organisateurs du congrès. J'exprime ma reconnaissance à Alastair Boyd, Lucinda Johnston et Trevor Deck qui se sont joints à moi pour planifier cet événement, ainsi qu'à Marc Stoeckle (gestion du Web), Rebecca Smith et Timothy Neufeldt (inscription et finances), et à Maureen Nevins pour sa direction et son engagement à l'égard de l'inclusivité durant tout le processus. II a fallu tout un village!

Les membres du groupe de travail visant le renouveau de l'ACBM ont continué de se rencontrer chaque mois et ont organisé deux séances de discussion ouverte en mars 2021 pour obtenir la rétroaction des membres sur la dernière ébauche des Axes stratégiques de I'ACBM (AS). Nous avons beaucoup profité de leur participation et de leurs commentaires lors de ces événements. Par conséquent, nous avons incorporé dans les AS les recommandations des participants. La version définitive de ce document est incluse dans le présent numéro de la Revue et sera officiellement mise en œuvre le 7 juin, dans le cadre du programme du congrès. Le 8 juin, 
about the SD document's next steps. I invite you to once again provide your feedback regarding the expanded participation of CAML members in the Association's work and governance. This participation will be crucial to future boards' success with the implementation of the proposed SD action items. I wish to express my thanks to the members of the Task Force for completing this important exercise, and for their unwavering commitment to echo the voice of the membership through the strategic planning vehicle.

In April, the CAML Board produced a statement of support and call for action following the troubling events that unfolded at Laurentian University. The statement appears in subsequent pages of this issue, was shared via our listserv, posted on our website, and is accessible from the Canadian Association of University Teachers website. I invite you to read the statement, and act to support higher education in our northern communities. As we continue to monitor the situation, I reiterate our solidarity with our Laurentian colleagues, and in particular with long-standing CAML member Desmond Maley.

I started my first President's message with a personal story and wrote about the young immigrant's impressions of music libraries and their collections. Allow me to close this last message with the thoughts of a proud Canadian citizen who had the good fortune and privilege to serve CAML nearly two decades later. If my thoughts were a word cloud, the most prominent words would be people, community, and interdependence. nous ouvrirons un débat au sujet des prochaines étapes à suivre relativement à ce dossier. Je vous invite de nouveau à nous faire parvenir votre opinion quant à une participation accrue des membres dans le travail et la gouvernance de I'ACBM. La participation de tous est essentielle à la réussite de la mise en œuvre des AS par le conseil d'administration. Je remercie les membres du groupe de travail pour leur finalisation de ce projet important de même que pour leur engagement indéfectible à se faire les messagers des membres au moyen de ce vecteur.

En avril, le CA de l'ACBM a émis une déclaration de soutien et un appel à l'action à l'Université Laurentienne à la suite des événements inquiétants qui s'y sont déroulés. Nous avons reproduit cette déclaration dans la Revue et I'avons aussi affichée sur notre serveur de liste et notre site Web. Elle paraît de plus sur le site Web de l'Association canadienne des professeures et des professeurs d'université. Je vous invite à lire cette déclaration et à soutenir l'enseignement supérieur dans les communautés du Nord. Tandis que nous continuons de surveiller la situation, nous exprimons notre solidarité avec nos collègues de l'Université Laurentienne, et en particulier Desmond Maley, un membre de longue date de l'ACBM.

Dans mon premier Message du président, je vous livrais mes impressions, en tant que jeune immigrant, sur les bibliothèques de musique et leurs collections. Permettez-moi de clore mon dernier message en vous transmettant les pensées d'un fier citoyen canadien ayant eu le bonheur et le privilège de servir l'ACBM presque vingt ans plus tard. Si mes paroles étaient un nuage de mots-clés, les plus importants à y paraître seraient gens, communauté et 
CAML is as strong as its members who, together, step up to make the Association bigger and better than any one of us can be individually. The past two years have proven that we can have a thriving journal, an evolving website, innovative committees, inclusive meetings, and so much more if and only if - many of us participate in the work of the Association. The fruits of our work enrich our professional lives and have a real impact on how we define ourselves as information professionals, and ultimately, on how we propagate and preserve music information in Canada.

In 2022 CAML will mark the birth centenary of our co-founder, Helmut Kallmann (19222012). Kallmann was the first Head of the Music Division at Library and Archives Canada (1970-1987). I extend my heartfelt congratulations to our incoming President Maureen Nevins, also of Library and Archives Canada, and shall do my best to support her as she guides us towards our collective goals.

\section{Houman Behzadi}

CAML President (2019-2021)

McGill University

houman.behzadi@mcgill.ca interdépendance. La vigueur de l'ACBM ne peut qu'égaler celle de ses membres, car ensemble, ils l'améliorent et l'affermissent, bien plus qu'une seule personne ne le pourrait. Au cours des deux dernières années, nous avons démontré être capables de publier un journal informatif, d'améliorer notre site Web, de former des comités novateurs, de tenir des réunions inclusives et bien plus encore, à condition que beaucoup de membres s'impliquent dans le travail de l'association - et seulement à cette condition. Le fruit de notre travail enrichit notre vie professionnelle, influence notre perception de nous-mêmes en tant que professionnelles et professionnels de l'information et, en définitive, influe sur notre propagation et notre préservation de l'information musicale au Canada.

En 2022, l'ACBM soulignera le centenaire de la naissance de son cofondateur, Helmut Kallmann (1922-2012). M. Kallmann a été le premier directeur de la division de musique à Bibliothèque et Archives Canada (1970-1987). J'en profite pour féliciter sincèrement la nouvelle présidente Maureen Nevins, qui travaille également à Bibliothèque et Archives Canada. Je ferai de mon mieux pour la soutenir dans l'atteinte de nos objectifs collectifs.

Houman Behzadi

Président de l'ACBM (2019-2021)

Université McGill

Houman.behzadi@mcgill.ca 